\title{
Genomic deletions of MSH2 and MLHI in colorectal cancer families detected by a novel mutation detection approach
}

\section{JJP Gille*,', FBL Hogervorst', G Pals', JTh Wijnen', RJ van Schooten', CJ Dommering', GA Meijer', ME Craanen ${ }^{3}$, PM Nederlof ${ }^{4}$, D de Jong ${ }^{4}$, CJ McElgunn', JP Schouten ${ }^{6}$ and FH Menko'}

'Department of Clinical Genetics and Human Genetics, Cancer Family Clinic, VU University Medical Center, 1007 MB Amsterdam, the Netherlands; ${ }^{2}$ Department of Pathology, VU University Medical Center, 1007 MB Amsterdam, the Netherlands; ${ }^{3}$ Department of Gastroenterology, VU University Medical Center, 1007 MB Amsterdam, the Netherlands; ${ }^{4}$ Cancer Family Clinic and Department of Pathology, Netherlands Cancer Institute, 1066 CX Amsterdam, the Netherlands; ${ }^{5}$ Department of Human Genetics, Leiden University Medical Center, 2300 RC Leiden, the Netherlands; ${ }^{6}$ MRC-Holland, 1057 SN Amsterdam, the Netherlands

Hereditary non-polyposis colorectal cancer is an autosomal dominant condition due to germline mutations in DNA-mismatchrepair genes, in particular $\mathrm{MLHI}, \mathrm{MSH} 2$ and $\mathrm{MSH}$. Here we describe the application of a novel technique for the detection of genomic deletions in MLHI and MSH2. This method, called multiplex ligation-dependent probe amplification, is a quantitative multiplex PCR approach to determine the relative copy number of each MLHI and MSH2 exon. Mutation screening of genes was performed in 126 colorectal cancer families selected on the basis of clinical criteria and in addition, for a subset of families, the presence of microsatellite instability (MSI-high) in tumours. Thirty-eight germline mutations were detected in 37 (29.4\%) of these kindreds, 31 of which have a predicted pathogenic effect. Among families with MSI-high tumours $65.7 \%$ harboured germline gene defects. Genomic deletions accounted for $54.8 \%$ of the pathogenic mutations. A complete deletion of the MLHI gene was detected in two families. The multiplex ligation-dependent probe amplification approach is a rapid method for the detection of genomic deletions in $\mathrm{MLHI}$ and $\mathrm{MSH}$ 2. In addition, it reveals alterations that might escape detection using conventional diagnostic techniques. Multiplex ligation-dependent probe amplification might be considered as an early step in the molecular diagnosis of hereditary non-polyposis colorectal cancer.

British Journal of Cancer (2002) 87, 892-897. doi: I0.1038/sj.bjc.6600565 www.bjcancer.com

(C) 2002 Cancer Research UK

Keywords: mismatch-repair; HNPCC; genomic deletions; Muir-Torre syndrome

\begin{abstract}
Hereditary non-polyposis colorectal cancer (HNPCC) is an autosomal dominant predisposition for early-onset colorectal cancer, endometrial cancer and other malignant tumours. Many HNPCC families fulfil the 'Amsterdam criteria' which require three colorectal cancer patients, vertical transmission and young age at diagnosis (Vasen et al, 1991). In about $50 \%$ of families that meet these criteria, germline mutations in one of the DNA-mismatchrepair (MMR) genes $M S H 2$ or $M L H 1$ are detected (Wijnen et al, 1997, 1998a). Virtually all colorectal tumours from MSH2 or MLH1 mutation carriers show microsatellite instability (MSI), which reflects the defect in DNA-mismatch-repair, and absence of expression of the MMR gene product involved. MSI is an important but not a specific marker of a germline MMR gene defect: the instability can also be due to acquired hypermethylation of MLH1 (Raedle et al, 2001). A minority of HNPCC families has a MSH6 defect or, exceptionally, a mutation in one of the other MMR genes (Liu et al, 2001). Tumours due to MSH6 mutations may or may not show MSI (Berends et al, 2002). Germline mutations in MMR genes can lead to a variety of clinical presentations, including sporadic early-onset colorectal cancer and familial endometrial cancer (Farrington et al, 1998;
\end{abstract}

*Correspondence: JJP Gille; Department of Clinical Genetics and Human Genetics, VU University Medical Center, PO Box 7057, 1007 MB Amsterdam, the Netherlands; E-mail: jjp.gille@vumc.nl

Received 29 April 2002; revised 17 July 2002; accepted 7 August 2002
Wijnen et al, 1999). Therefore, additional clinical criteria were developed which may indicate an MMR gene defect, in particular the Bethesda and Amsterdam II criteria (Rodriguez-Bigas et al, 1997; Vasen et al, 1999). Identification of a germline defect in colorectal cancer patients is crucial to establish the etiology of the disease and to direct clinical decision making for patients and family members.

At present, mutation detection of DNA-mismatch-repair genes is often performed by DGGE (Denaturing Gradient Gel Electrophoresis), DHPLC (Denaturing High Performance Liquid Chromatography), SSCA (Single Strand Conformation Analysis) and direct DNA sequencing. With these methods single base substitutions and small deletions and insertions can be detected. However, genomic deletions, i.e. deletions of one or more entire exons as well as duplications of exons will not be identified by these techniques. Detection of this class of mutations is important since they are an important cause of hereditary non-polyposis colorectal cancer (Wijnen et al, 1998b).

Conventionally, the main technique used for the detection of genomic deletions in MMR genes is Southern blotting (Wijnen et al, 1998b). However, Southern blot analysis has several drawbacks: the method is laborious and time-consuming and requires a relatively large amount of high-quality DNA. Therefore, alternative methods were developed based on (semi-) quantitative PCR (Charbonnier et al, 2000, 2002; Wang et al, 2002).

Here we describe the value of a new technique, called Multiplex Ligation-dependent Probe Amplification (MLPA), for determina- 
tion of the relative copy numbers of DNA sequences, and application of this method for the analysis of genomic deletions in $\mathrm{MSH} 2$ and $M L H 1$.

\section{MATERIALS AND METHODS}

We studied a cohort of colorectal cancer families investigated at the Cancer Family Clinics of the VU University Medical Center and the Netherlands Cancer Institute, Amsterdam, the Netherlands. The aim of this study was to assess the value of the MLPA test for the detection of genomic MSH2- or MLH1-deletions.

In 126 colorectal cancer families germline mutation analysis of MSH2, MLH1 and/or MSH6 was performed. MSH1 and MLH2 were analysed in 103 kindreds. MSH6 was analysed in most families negative for $M S H 2$ and $M L H 1$. In the other 23 families, all with MSI-stable or MSI-low tumours, only MSH6 was examined.
The pedigree data either fulfilled the Amsterdam criteria I or II for HNPCC or less stringent criteria, usually one or several of the Bethesda criteria ('suspected HNPCC'). Germline mutation screening of MMR genes was performed using DGGE or SSCA in combination with DHPLC for MLH1 and MSH2 and DGGE for MSH6. Investigation of MSI in tumours was performed according to standard procedures (Boland et al, 1998). Southern blotting of MSH2 and MLH1 was performed in one institution (VUMC) for families with MSI-high tumours and a previous negative screening for MMR gene defects. DNA samples from all 126 families were subjected to MLPA analysis. Informed consent was obtained from all patients who underwent DNA-based diagnosis.

In MLPA, illustrated in Figure 1A, probes are used that consist of two oligonucleotides, both having a sequence complementary to a part of a target sequence at one site and a universal primer annealing sequence at the other site. Both hemi-probes can hybridize directly adjacent to each other to a target genomic sequence. If

A
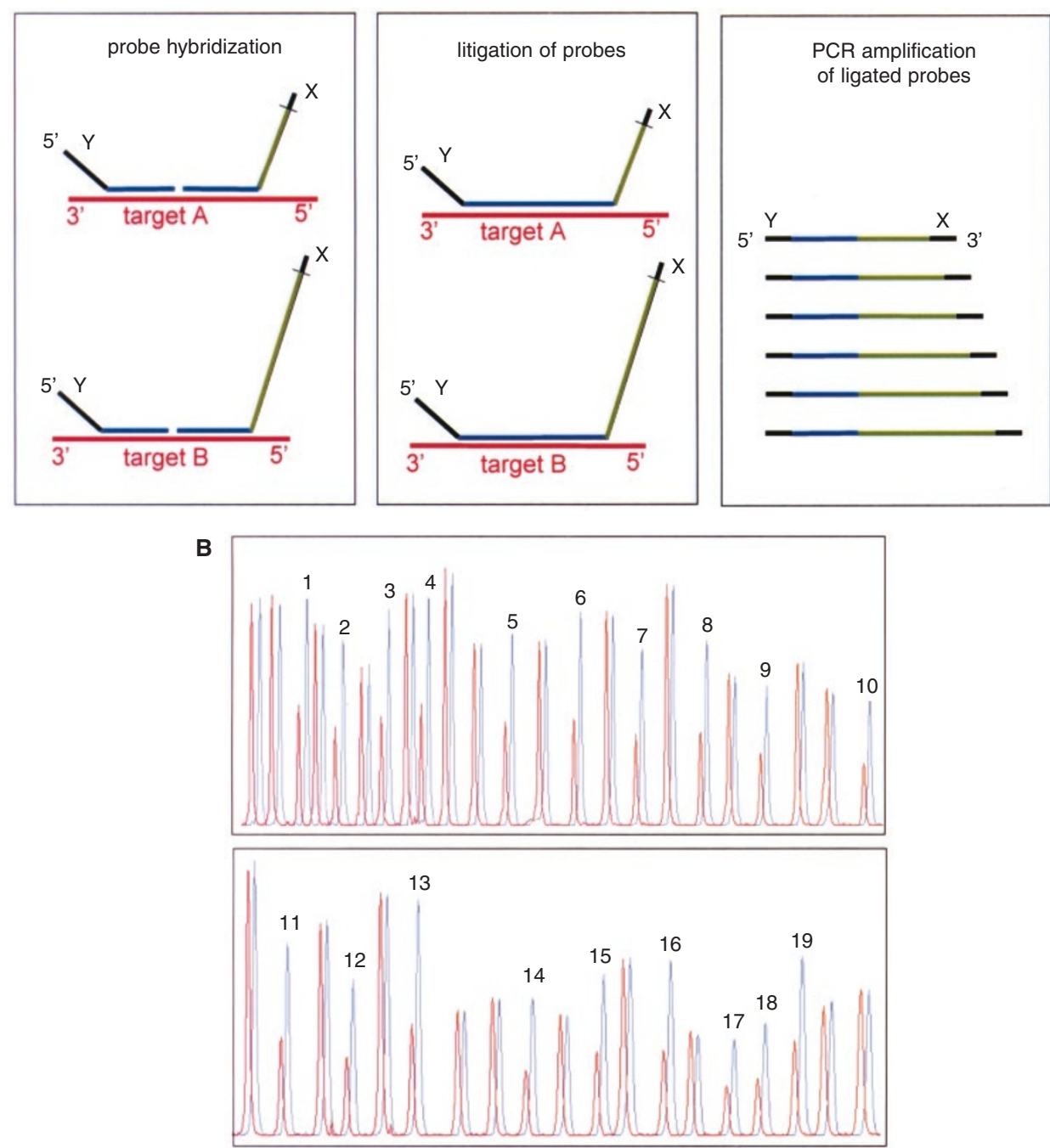

Figure I (A) Multiplex Ligation-dependent Probe Amplification (MLPA). Denatured genomic DNA (50-500 ng) is hybridised with a mixture of 42 probes. Each MLPA probe consists of two oligonucleotides. The two parts of each probe hybridise to adjacent target sequences and are ligated by a thermostable ligase. All probe ligation products are amplified simultaneously by PCR using a single primer pair. The amplification product of each probe has a unique length (130-472 bp). Amplification products are separated by capillary electrophoresis (ABI model 310 or ABI 3700). Relative amounts of probe amplification products reflect the relative copy number of target sequences. (B) Deletion of the entire MLHI gene detected by MLPA. Normalised MLPA peak pattern from the index patient of family CI 49 (red) and from control DNA (blue) plotted in one figure for easy comparison. MLHI peaks are labelled with their exon numbers. Unlabelled peaks represent MSH2 exons and control genes. 
hybridized, the hemi-probes can be ligated and subsequently be amplified by PCR. Non-hybridized hemi-probes do not have to be removed since they can not be ligated and consequently will not be amplified. By using probes with amplification products of different lengths, multiple probes can be used in one reaction and be separated by gel electrophoresis for quantification (Schouten et al, 2002).

The MLPA test for MSH2 and MLH1 was obtained from MRCHolland, Amsterdam, the Netherlands. The probe mix contains 16 exon probes for $M S H 2,19$ exon probes for $M L H 1$, and seven control probes specific for DNA sequences outside the MSH2 and $M L H 1$ genes. Details on probe sequences can be found on http://www.mrc-holland.com. All incubations were performed in a PCR machine with heated lid. Genomic DNA (50-500 ng) in $5 \mu \mathrm{l} \mathrm{TE}$ was denatured at $98^{\circ} \mathrm{C}$ for $5 \mathrm{~min}$. Next, $3 \mu \mathrm{l}$ probe mix was added and the mix was heated at $95^{\circ} \mathrm{C}$ for $1 \mathrm{~min}$. and incubated at $60^{\circ} \mathrm{C}$ for $16 \mathrm{~h}$ ('overnight'). Ligation was performed using heat-stable Ligase- 65 enzyme at $54^{\circ} \mathrm{C}$ for $15 \mathrm{~min}$, followed by ligase inactivation at $98^{\circ} \mathrm{C}$ for $2 \mathrm{~min}$. Next, $10 \mu \mathrm{l}$ ligation mix was added to $40 \mu \mathrm{l}$ PCR buffer containing dNTPs, Taq polymerase and PCR primers (one unlabelled and one FAM-labelled primer). The reaction mixture was preheated at $95^{\circ} \mathrm{C}$ for $1 \mathrm{~min}$. followed by 32 cycles of denaturation at $95^{\circ} \mathrm{C}$ for $30 \mathrm{~s}$, annealing at $60^{\circ} \mathrm{C}$ for $30 \mathrm{~s}$ and extension at $72^{\circ} \mathrm{C}$ for $1 \mathrm{~min}$. A final extension was performed at $72^{\circ} \mathrm{C}$ for $20 \mathrm{~min}$. Fragment analysis was carried out on ABI model 310 or 3700 capillary sequencer (Applied Biosystems, Forster City, CA, USA) using TAMRA-500 or ROX-500 as size standards. A peak pattern of 42 peaks ranging in size from 130 to $472 \mathrm{nt}$ is obtained.

Data analysis was performed using Genescan and Genotyper software (Applied Biosystems). For analysing a small series of samples, visual inspection of the peak pattern of a patient's sample superimposed over a peak pattern of a control is very suitable (see Figure 1B). For analysing large series of samples, peak areas were imported into Excel spreadsheets and peak fractions were calculated by dividing the peak area of a certain probe by the sum of peak areas of all control probes in a certain sample. Subsequently, this relative peak area of each probe was divided by the average relative peak area of this probe in control samples. In normal individuals this calculation will result in a value of 1.0 representing two copies of the target sequence in the sample.

\section{RESULTS}

The yield of germline mutation analysis according to the clinical subgroup and the MSI status of tumours is given in Table 1 . We found germline mutations in $37(29.4 \%)$ of the 126 colorectal cancer families. The characteristics of these families are summarised in Table 2. Thirty-eight germline mutations were found, including a double mutation in one kindred (family C222: a splice defect and an unclassified variant of MLH1), 20 in MSH2, 15 in MLH1 and three in MSH6. Seven (six different) DNA alterations were of unknown clinical significance. Thirteen genomic deletions were identified in $\mathrm{MSH} 2$ and four in $\mathrm{MLH1}$, including a deletion of the entire $M L H 1$ gene in two families (Figure 1B). These two kindreds were found to have a common ancestor in the eighteenth century. The clinical picture is summarised in Figure 2. All genomic deletions detected by Southern blotting were confirmed by MLPA.

\section{DISCUSSION}

We found a high frequency of genomic deletions in $\mathrm{MSH} 2$ and MLH1 in a large cohort of colorectal cancer families. The new MLPA technique efficiently detected these deletions. In general, the yield of MMR gene mutation analysis in colorectal cancer families depends upon: (1) the selection of families based on clinical criteria, (2) the MSI status of tumours and/or immunohistochemical expression of MMR gene products, (3) the methods used for germline mutation analysis and (4) the interpretation of mutations as pathogenic $v s$ non-pathogenic.

The families we studied include a wide range of clinical conditions with varying indications of HNPCC. They were classified into two main groups: those that fulfil the Amsterdam criteria (I or II) and other 'suspected' families. Families from the latter group generally satisfied one or more of the Bethesda criteria. It should be noted that the description of a given family according to the Amsterdam or Bethesda criteria does not always give the most complete clinical information. For example, MuirTorre syndrome skin lesions were observed in several families from our study group and strongly indicate HNPCC; however, they are not mentioned in the above-mentioned criteria. In addition, many families seen in the clinic have a strong but unconfirmed family history of colorectal cancer whereas the Amsterdam and Bethesda criteria require histologically confirmed diagnoses.

In families that meet the stringent Amsterdam criteria, pathogenic MSH2 or MLH1 mutations have been detected in about $50 \%$ of kindreds (Wijnen et al, 1997). The same yield of about $50 \%$ is found for families with less clinical indications of HNPCC but which, in addition, have MSI-high tumours (Terdiman et al, 2001; Raedle et al, 2001). Among families that only fulfil clinical criteria, usually not as stringent as the Amsterdam criteria, mutations are detected in about $30 \%$ of kindreds (Wijnen et al, 1998a; Bapat et al, 1999; Lamberti et al, 1999; Syngal et al, 2000; Wahlberg et al, 2002). Depending on the specific subgroup which

Table I Yield of germline DNA-mismatch-repair gene mutation analysis in 126 colorectal cancer families

\begin{tabular}{|c|c|c|c|c|c|c|}
\hline \multirow[b]{2}{*}{ Description of the pedigree } & \multirow{2}{*}{$\begin{array}{l}\text { Number } \\
\text { of families }\end{array}$} & \multicolumn{3}{|c|}{$\begin{array}{l}\text { Number of germline mutations } \\
\text { for each gene }\end{array}$} & \multirow{2}{*}{$\begin{array}{c}\text { Total number } \\
\text { of families with } \\
\text { germline mutations }\end{array}$} & \multirow{2}{*}{$\begin{array}{l}\% \text { of families with } \\
\text { mutations and } 95 \% \text { confidence } \\
\text { interval (binomial exact) }\end{array}$} \\
\hline & & MSH2 & MLHI & MSH6 & & \\
\hline\|\|$^{\mathrm{a}}$ & 18 & 3 & 3 & 0 & 6 & $33.3(13.3-59.0)$ \\
\hline III \& MSI-S or MSI-L & 64 & 2 & । & 1 & 4 & $6.3(1.7-15.2)$ \\
\hline III \& MSI-H & 22 & 5 & $7^{\mathrm{b}}$ & 1 & $12^{\mathrm{b}}$ & $54.5(32.2-75.6)$ \\
\hline $\mid / / \|^{\mathrm{a}}$ & 4 & 3 & । & 0 & 4 & $100(39.7-100)$ \\
\hline I/II \& MSI-S or MSI-L & 5 & 0 & 0 & 0 & 0 & $0(0-52.2)$ \\
\hline I/II \& MSI-H & 13 & 7 & 3 & 1 & | | & $84.6(54.6-98.1)$ \\
\hline All MSI-S or MSI-L families & 69 & 2 & I & $\mathbf{I}$ & 4 & $5.8(1.6-14.1)$ \\
\hline All MSI-H families & 35 & 12 & 10 & 2 & $23^{b}$ & $65.7(47.8-80.9)$ \\
\hline ALL FAMILIES & 126 & 20 & 15 & 3 & $37^{b}$ & $29.4(21.6-38.1)$ \\
\hline
\end{tabular}

I/II=Amsterdam criteria I/II; III=suspected HNPCC; MSI=microsatellite instability. S=stable; L=low; H=high (two families had both MSI-H and MSI-S or MSI-L tumours; ${ }^{\text {MSI not }}$ tested or MSI could not be assessed; ${ }^{b}$ One family had two MLHI mutations (family C222: splice defect \& unclassified variant) 
Table 2 DNA-mismatch-repair-gene germline mutations in 37 colorectal cancer families

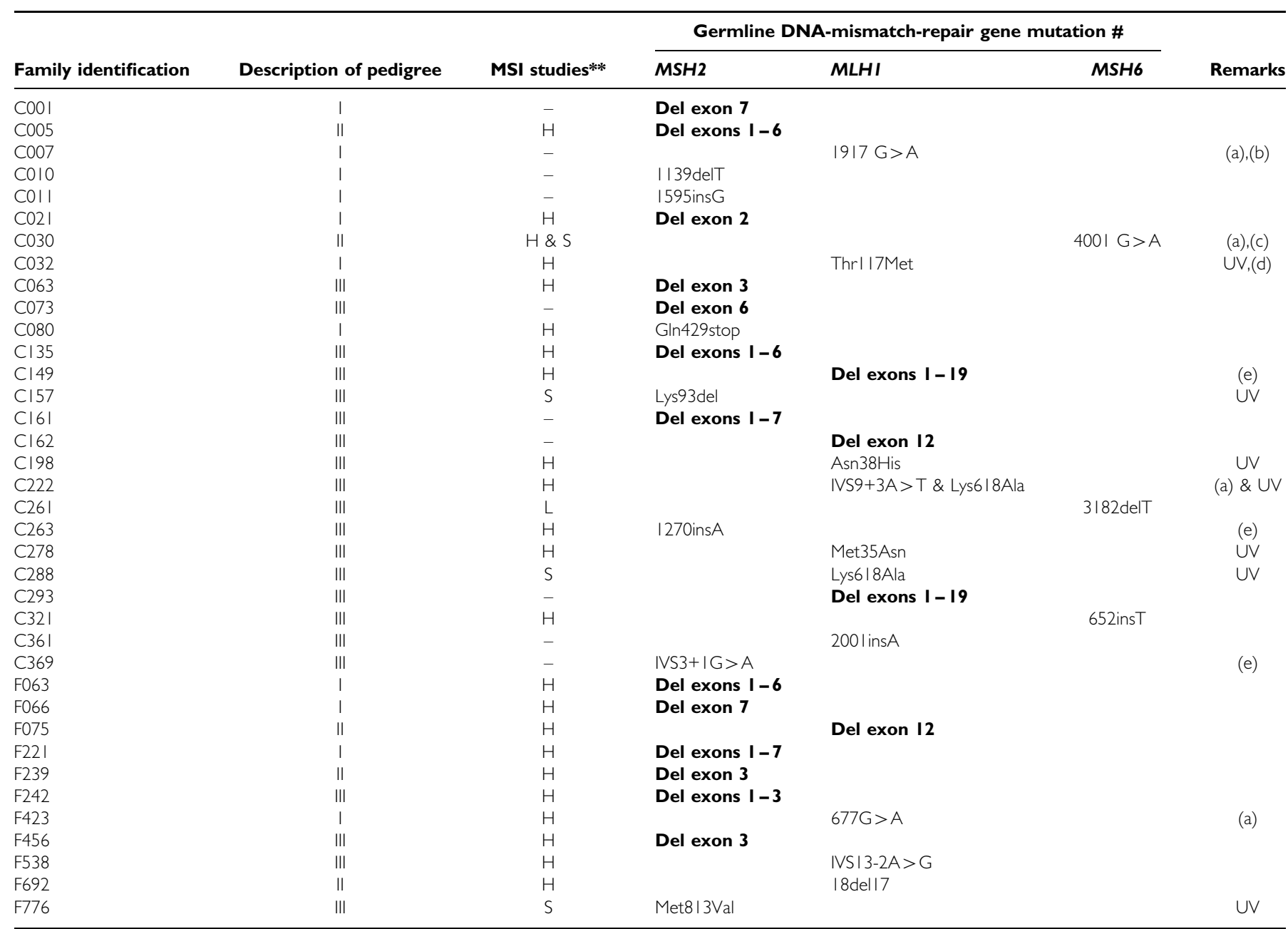

I/II=Amsterdam criteria I/II; III=suspected HNPCC; **: hMSI=microsatellite instability; S=stable; L=low; H=high; -: MSI-studies not performed; \#: mutations detected by MLPA indicated in bold type; (a) splice defect; (b) kindred also described by Wijnen et al, 1997 (NL-4); (c) kindred also described by Menko et al, 1994 ; Wijnen et al, 1999 (NA-22); (d) pathogenicity assessed by in vitro test (Trojan et al, 2002); (e) clinical picture includes Muir-Torre syndrome; UV=unclassified variant

is tested, the frequency of mutations may be lower than $10 \%$ or higher than $90 \%$.

Our mutation yield was $5.8 \%$ for families with MSI-S or MSI-L tumours and $65.7 \%$ for families with MSI-H tumours (Table 1). Our data support the notion that screening for MSI in tumours is an efficient prescreening tool for mutation analysis.

Since we included a technique for the detection of genomic deletions which revealed a high frequency of this class of mutations, one might argue that a frequency of non-deletion mutations of 20 out of 126 kindreds $(15.9 \%)$ is lower than one would expect. Probably there are two main reasons for the low percentage of non-deletion mutations. First, we performed mutation analysis in a relatively large group of families which did not meet the Amsterdam criteria (I or II) and, in addition, had MSI-stable or MSI-low tumours. In 64 of these families we found only four $(6.3 \%)$ germline mutations. These mutations include three unclassified variants in MSH2 and MSH1 and one pathogenic MSH6 mutation. It has been observed before that deleterious MSH6 mutations may be accompanied by MSI-low tumours (Berends et al, 2002). Second, in several families all affected individuals had died and, consequently, only at-risk family members were available for testing.
The methods we used for the analysis of point mutations were DGGE or SSCA in combination with DHPLC for MSH2 and MLH1 and DGGE for MSH6. These techniques are highly sensitive and specific for the detection of mutations in the coding regions of these genes (Wahlberg et al, 1999). Mutations in the promoter regions of $M S H 2$ and $M L H 1$ will not be detected by these methods; however, they seem to play a limited role (Shin et al, 2002). We found six different mutations in $\mathrm{MSH} 2$ and $\mathrm{MLH1}$ categorised as unclassified variants; their clinical significance is uncertain. However, the Thr117Met variant in MLH1 most probably has a pathogenic effect as demonstrated in a recently developed in vitro assay (Trojan et al, 2002).

In our cohort of colorectal cancer families more than $50 \%$ of the pathogenic mutations were genomic deletions. Evidently, genomic deletions in $M L H 1$ and $M S H 2$ are an important cause of HNPCC in Dutch colorectal cancer families. It has been reported previously that $\mathrm{MSH} 2$ genomic deletions are frequent in this group. Haplotype analysis of the kindreds sharing the same deletions failed to show evidence of a founder effect (Wijnen et al, 1998b). Only two MLH1 deletions had been reported at that time, one of which was a founder mutation that accounted for a large proportion of HNPCC kindreds in the Finnish population (Nyström-Lahti et al, 1995; Mauillon et al, 1996). In a recent study of German 

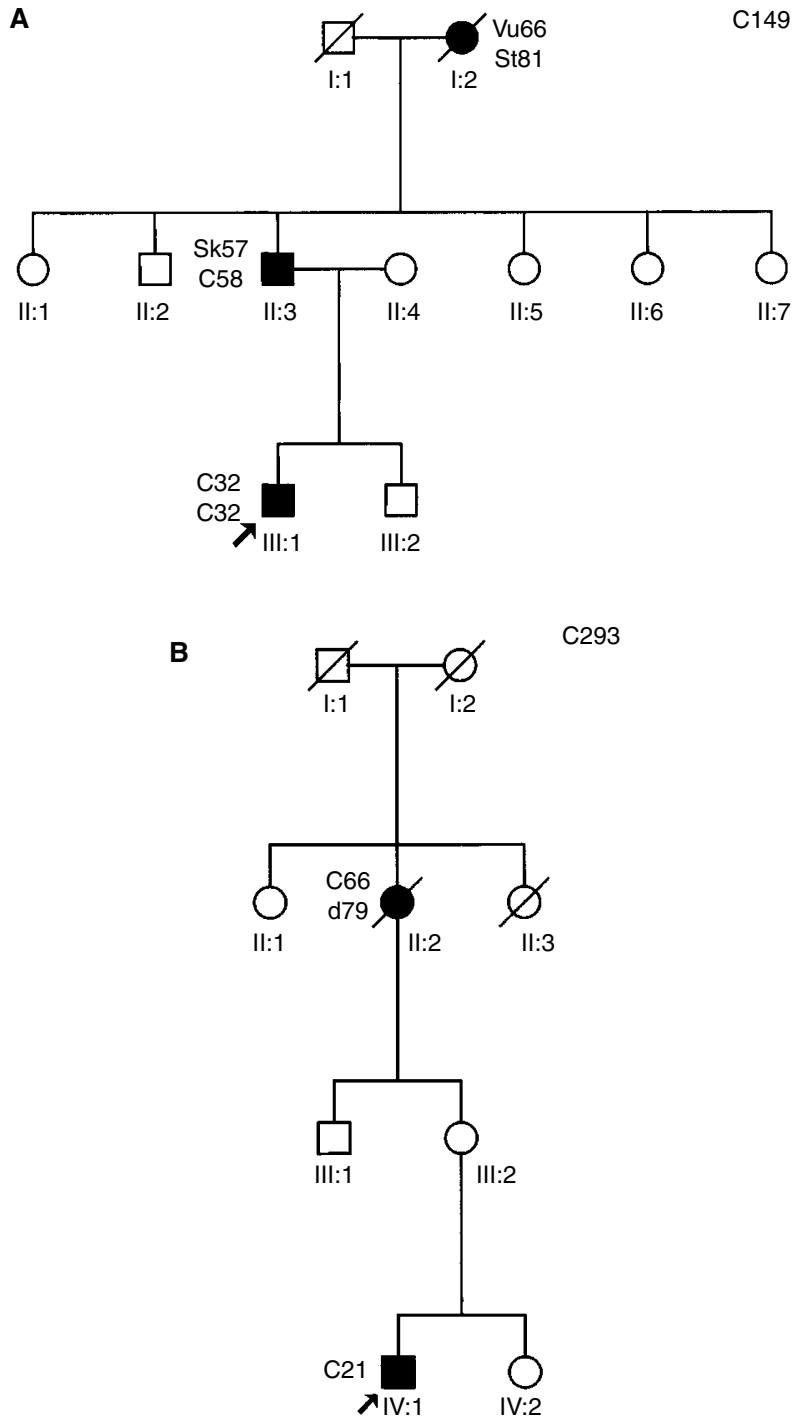

Figure 2 (A) Family $\mathrm{Cl}$ 49. The index patient had a double colonic tumour at age 32 , his father had colonic cancer preceded by skin tumours including Muir-Torre syndrome skin lesions (sebaceous gland adenoma, kerato-acanthoma, planocellular cancer). Patient I-2 had primary cancers of the vulva and stomach. (B) Family C293. The index patient had colonic cancer at the age of 21 years. His unaffected mother had a tubular adenoma on colonoscopic screening, his maternal grandmother had late-onset colonic cancer. Family members I-2 (CI49) and I-I (C293) have a common ancestor.

\section{REFERENCES}

Armour JAL, Sismani C, Patsalis PC, Cross G (2000) Measurement of locus copy number by hybridisation with amplifiable probes. Nucl Acids Res 28: $605-609$

Bapat BV, Madlensky L, Temple LKF, Hiruki T, Redston M, Baron DL, Xia L, Marcus VA, Soravia C, Mitri A, Shen W, Gryfe R, Berk T, Chodirker BN, Cohen Z, Gallinger S (1999) Family history characteristics, tumor microsatellite instability and germline $\mathrm{MSH} 2$ and $\mathrm{MLH} 1$ mutations in hereditary colorectal cancer. Hum Genet 104: $167-176$

Berends MJW, Wu Y, Sijmons RH, Mensink RGJ, van der Sluis T, HordijkHos JM, de Vries EGE, Hollema H, Karrenbeld A, Buys CHCM, van der Zee AGJ, Hofstra RMW, Kleibeuker JH (2002) Molecular and clinical characteristics of MSH6 variants: an analysis of 25 index carriers of a germline variant. Am J Hum Genet 70: 26-37
HNPCC kindreds a predominance of MLH1 deletions was found (Wang et al, 2002). Recently, deletion mutations have also been demonstrated in series of European and US colorectal cancer kindreds, but at a much lower frequency than in our study group (Wijnen JTh, personal communication). We found 17 genomic deletions, 13 in $M S H 2$ and four in $M L H 1$. These included at least nine different subtypes, which might imply that the high frequency of deletions in our study group is not caused by a strong founder effect. However, five deletions occurred in multiple kindreds and a common ancestor was demonstrated for the MLH1 deletion. Future studies will clarify the frequency and background of genomic deletions in $M S H 2$ and $M L H 1$ in different populations.

A deletion of the entire $M L H 1$ gene has not been described before. In the two kindreds involved, the clinical expression included Muir-Torre syndrome and very-early-onset colonic cancer. A deletion of the complete $\mathrm{MSH} 2$ gene in an HNPCC family was recently described by Wang et al (2002).

In summary, the MLPA technique is a fast and efficient test for the detection of genomic deletions in MMR genes. In contrast with the PCR- based techniques described by Charbonnier et al (2002) and Wang et al (2002) deletion screening of MSH2 and MLH1 by MLPA can be performed in a single procedure. Compared with the MAPH method developed recently (Armour et al, 2000) MLPA is easier to perform. The technique allows the detection of deletions that might escape detection using Southern blot analysis. In particular, interpretation of Southern blotting results may be difficult in case of the deletion of an entire gene.

Clearly, screening for genomic deletions in $M S H 2$ and $M L H 1$ is an essential procedure for the molecular diagnosis of HNPCC. Due to the advantages of the MLPA technique, screening for these deletions might be considered as an early step in MMR gene mutation analysis.

\section{ACKNOWLEDGEMENTS}

We thank Bertus Kuyt for genealogical investigation, Resie van Spaendonk for molecular studies, Hans Berkhof for statistical advice and Ilona Hartog and Bea Koudhoofd for secretarial assistance. CJ McElgunn is recipient of a Marie Curie Industrial Host fellowship.
Boland CR, Thibodeau SN, Hamilton SR, Sidransky D, Eshleman JR, Burt RW, Meltzer SJ, Rodriguez-Bigaz MA, Fodde R, Ranzani GN, Srivastava S (1998) A National Cancer Institute workshop on microsatellite instability for cancer detection and familial predisposition: development of international criteria for the determination of microsatellite instability in colorectal cancer. Cancer Res 58: $5248-5257$

Charbonnier F, Raux G, Wang Q, Drouot N, Cordier F, Limacher J-M, Saurin J-C, Puisieux A, Olschwang S, Frebourg T (2000) Detection of exon deletions and duplications of the mismatch repair genes in hereditary nonpolyposis colorectal cancer families using multiplex polymerase chain reaction of short fluorescent fragments. Cancer Res 60: 2760-2763 
Charbonnier F, Olschwang S, Wang Q, Boisson C, Martin C, Buisine M-P, Puisieux A, Frebourg T (2002) MSH2 in contrast to MLH1 and MSH6 is frequently inactivated by exonic and promoter rearrangements in hereditary nonpolyposis colorectal cancer. Cancer Res 62: 848-853

Farrington SM, Lin-Goerke J, Ling J, Wang Y, Burczak JD, Robbins DJ, Dunlop MG (1998) Systematic analysis of hMSH2 and hMLH1 in young colon cancer patients and controls. Am J Hum Genet 63: 749-759

Lamberti C, Kruse R, Ruelfs C, Caspari R, Wang Y, Jungck M, Mathiak M, Malayeri HRH, Friedl W, Sauerbruch T, Propping P (1999) Microsatellite instability - a useful diagnostic tool to select patients at high risk for hereditary non-polyposis colorectal cancer: a study in different groups of patients with colorectal cancer. Gut 44: 839-843

Liu T, Yan H, Kuismanen S, Percesepe A, Bisgaard M-L, Pedroni M, Benatti P, Kinzler KW, Vogelstein B, Ponz de Leon M, Peltomäki P, Lindblom A (2001) The role of $h P M S 1$ and $h P M S 2$ in predisposing to colorectal cancer. Cancer Res 61: 7798-7802

Mauillon JL, Michel P, Limacher J-M, Latouche J-B, Dechelotte P, Charbonnier F, Martin C, Moreau V, Metayer J, Paillot B, Frebourg T (1996) Identification of novel germline $h M L H 1$ mutations including a $22 \mathrm{~kb}$ Alu-mediated deletion in patients with familial colorectal cancer. Cancer Res 56: $5728-5733$

Menko FH, Verheijen RHM, Everhardt E, Louwé LA, Wijnen JTh, Band SC, Felt-Bersma RJF, Vasen HFA, Meera Khan P (1994) Endometrial cancer in four sisters: report of a kindred with presumed cancer family syndrome. Gynecol Oncol 54: 171-174

Nyström-Lahti M, Kristo P, Nicolaides NC, Chang S-Y, Aaltonen LA, Moisio A-L, Järvinen HJ, Mecklin J-P, Kinzler KW, Vogelstein B, de la Chapelle A, Peltomäki P (1995) Founding mutations and Alu-mediated recombination in hereditary colon cancer. Nat Med 1: 1203-1206

Raedle J, Trojan J, Brieger A, Weber N, Schäfer D, Plotz G, Staib-Sebler E, Kriener S, Lorenz M, Zeuzem S (2001) Bethesda guidelines: relation to microsatellite instability and $M L H 1$ promoter methylation in patients with colorectal cancer. Ann Intern Med 135: 566-576

Rodriguez-Bigas MA, Boland CR, Hamilton SR, Henson DE, Jass JR, Meera Khan P, Lynch H, Perucho M, Smyrk T, Sobin L, Srivastava S (1997) A National Cancer Institute workshop on hereditary nonpolyposis colorectal cancer syndrome: meeting highlights and Bethesda guidelines. JNCI 89: $1758-1762$

Schouten JP, McElgunn CJ, Waaijer R, Zwijnenburg D, Diepvens F, Pals G (2002) Relative quantification of 40 nucleic acid sequences by multiplex ligation-dependent probe amplification. Nucl Acids Res 30: e57

Shin K-H, Shin J-H, Kim J-H, Park J-G (2002) Mutational analysis of promoters of mismatch repair genes $h M S H 2$ and $h M L H 1$ in hereditary nonpolyposis colorectal cancer and early onset colorectal cancer patients: identification of three novel germ-line mutations in promoter of the hMSH2 gene. Cancer Res 62: 38-42
Syngal S, Fox EA, Eng C, Kolodner RD, Garber JE (2000) Sensitivity and specificity of clinical criteria for hereditary non-polyposis colorectal cancer associated mutations in MSH2 and MLH1. J Med Genet 37: 641-645

Terdiman JP, Gum JR, Conrad PG, Miller GA, Weinberg V, Crawley SC, Levin TR, Reeves C, Schmitt A, Hepburn M, Sleisenger MH, Kim YS (2001) Efficient detection of hereditary nonpolyposis colorectal cancer gene carriers by screening for tumor microsatellite instability before germline genetic testing. Gastroenterology 120: $21-30$

Trojan J, Zeuzem S, Randolph A, Hemmerle C, Brieger A, Raedle J, Plotz G, Jiricny J, Marra G (2002) Functional analysis of hMLH1 variants and HNPCC-related mutations using a human expression system. Gastroenterology 122: $211-219$

Vasen HFA, Mecklin J-P, Meera Khan P, Lynch HT (1991) The International Collaborative Group on hereditary non-polyposis colorectal cancer (ICGHNPCC). Dis Colon Rectum 34: 424-425

Vasen HFA, Watson P, Mecklin J-P, Lynch HT and the ICG-HNPCC (1999) New clinical criteria for hereditary nonpolyposis colorectal cancer (HNPCC, Lynch syndrome) proposed by the International Collaborative Group on HNPCC. Gastroenterology 116: 1453-1456

Wahlberg S, Liu T, Lindblom P, Lindblom A (1999) Various mutation screening techniques in the DNA mismatch repair genes hMSH2 and hMLH1. Genet Test 3: 259-264

Wahlberg SS, Schmeits J, Thomas G, Loda M, Garber J, Syngal S, Kolodner RD, Fox E (2002) Evaluation of microsatellite instability and immunohistochemistry for the prediction of germ-line $\mathrm{MSH} 2$ and $\mathrm{MLH1}$ mutations in hereditary nonpolyposis colon cancer families. Cancer Res 62: 3485-3492

Wang Y, Friedl W, Sengteller M, Jungck M, Filges I, Propping P, Mangold E (2002) A modified multiplex PCR assay for detection of large deletions in MSH2 and MLH1. Hum Mutat 19: 279-286

Wijnen J, Meera Khan P, Vasen H, van der Klift H, Mulder A, van LeeuwenCornelisse I, Bakker B, Losekoot M, Møller P, Fodde R (1997) Hereditary nonpolyposis colorectal cancer families not complying with the Amsterdam criteria show extremely low frequency of mismatch-repair gene mutations. Am J Hum Genet 61: 329-335

Wijnen JT, Vasen HFA, Meera Khan P, Zwinderman AH, van der Klift H, Mulder A, Tops C, Møller P, Fodde R (1998a) Clinical findings with implications for genetic testing in families with clustering of colorectal cancer. $\mathrm{N}$ Engl J Med 339: $511-518$

Wijnen J, van der Klift H, Vasen H, Meera Khan P, Menko F, Tops C, Meijers Heijboer H, Lindhout D, Møller P, Fodde R (1998b) MSH2 genomic deletions are a frequent cause of HNPCC. Nat Genet 20: 326-328

Wijnen J, de Leeuw W, Vasen H, van der Klift H, Møller P, Stormorken A, Meijers-Heijboer H, Lindhout D, Menko F, Vossen S, Möslein G, Tops C, Bröcker-Vriends A, Wu Y, Hofstra R, Sijmons R, Cornelisse C, Morreau H, Fodde R (1999) Familial endometrial cancer in female carriers of MSH6 germ-line mutations. Nat Genet 23: 142-144 